\title{
RESPON PENGGUNAAN BERBAGAI BAHAN AKTIVATOR PADA AKTIVASI PARTENOGENESIS OOSIT KAMBING HASIL IVM
}

\author{
Kholifah Holil ${ }^{1}$, Eva Ari Wahyuni ${ }^{2}$, Hari Soepriandono ${ }^{3}$, Gatot Ciptadi $^{4}$
}

\begin{abstract}
Parthenogenetic activation is one method that can be used to determine the quality of IVM oocytes results before further use to other reproductive technologies (IVF and transfer core). In parthenogenetic activation can be used various activators such as ethanol, Ca Ionophore, and Crude Sperm Extract (CSE). Therefore, the aim of this experiment is to know the response use a variety of materials activator of parthenogenetic activation of goat oocytes IVM.

The sample used in this experiment was oocytes aspirated from goat ovarian follicles taken from RPH Sukun of Malang. Oocytes were matured for $24 \mathrm{hr}$ in TCM199 supplemented with fetal bovine serum (FBS), follicle-stimulating hormone (FSH) and lutheinizing hormone ( $\mathrm{LH}$ ) at a temperature of $38,5^{\circ} \mathrm{C}$ and $5 \% \mathrm{CO}_{2}$ in humidified air. After another 30 hours of in vitro maturation, they were then activated by various treatments. The treatment of experiment are treatment 1, activation using ethanol $7 \%$ for 7 minute, treament 2, activation using Ca Ionophore $20 \mu M$ for 7 minute. Treatment 3 , activation using CSE 2,5 $\mu \mathrm{g} / \mathrm{ml}$ for $2 \mathrm{hr}$.

Based on the result of research, it is showed that activation by using 7\% ethanol for 7 minutes is able to produce cleavage rate of $70.40 \%$. Activation by Ca Ionophore $20 \mu M$ for 7 minutes is able to produce cleavage rate of $52.75 \%$. While the use of CSE activation with $2.5 \mathrm{ug} / \mathrm{ml}$ for 2 hours produces cleavage rate of $36.33 \%$. Thus it can be concluded that the goat oocyte IVM able to respond to a variety of materials activators on parthenogenetic activation performed. The highest response given by the successive results goat IVM oocytes activated using 7\% ethanol for 7 minutes, $20 \mu M$ Ca Ionophore for 7 minutes, and the CSE 2.5 microg / ml for 2 hours.
\end{abstract}

Keywords: Parthenogenetic activation, goat oocytes IVM, etanol, calsium ionophore, Crude Sperm Extract (CSE).

\footnotetext{
Staff Pengajar Jurusan Biologi, Fak. Saintek, Universitas Islam Negeri (UIN) Maliki Malang

2 Staff Pengajar Jurusan Kelautan, Fakultas Pertanian, Universitas Trunojoyo Madura

${ }^{3}$ Staff Pengajar Jurusan Biologi, Fakultas Saintek, Universitas AirlanggaSurabaya

${ }^{4}$ Staff Pengajar Jurusan Produksi Ternak, Fakultas Peternakan, Universitas Brawijaya Malang
} 



\section{PENDAHULUAN}

Oosit merupakan syarat utama untuk menunjang teknologi reproduksi. Oosit yang berkualitas mampu mendukung keberhasilan dalam in vitro fertilisation (IVF) maupun dalam nuclear transfer (NT).

Model untuk melihat kontribusi oosit dalam teknologi tersebut adalah dengan melihat perannya dalam partenogenesis.

Partenogenesis merupakan proses pembentukan embrio dari oosit matur tanpa peran dari sperma. Proses pembentukan ini dimungkinkan karena bahan aktivator yang digunakan untuk mengaktivasi oosit mampu memicu oosit untuk menyelesaikan fase-fase dalam pembelahannya.

Secara umum oosit mamalia ketika lahir ada dalam tahap diploten (fase profase pada meiosis I) dan pada saat siap berfertilisasi oosit ada dalam fase MII. Oosit yang ada dalam MII tersebut baru bisa menyelesaikan meiosis jika mengalami fertilisasi. Nurse (1990) mengemukakan bahwa MII pada oosit terjadi karena tingginya aktivitas Maturing Promoting Factor (MPF) yang merupakan protein kompleks yang tersusun atas 2 subunit yaitu p34 ${ }^{\text {cdc2 }}$ dan cyclin B. Aktivasi MPF diinduksi oleh cyclin B yang dalam proses ini memerlukan fosforilasi threonin dan defosforilasi tirosin pada $\mathrm{p} 34^{\text {cdc2 }}$.

Penggunaan bahan activator tertentu dalam ativasi parthenogenesis memungkinkan oosit untuk memberikan respon yang berbeda-beda. Respon tersebut dapat kita lihat dari embrio yang terbentuk. Aktivator yang digunakan dalam proses ini dapat berasal dari bahan-bahan kimia seperti calsium ionophore, strontium, sikloheksimida atau 6-DMAP, etanol, dan juga dapat dilakukan secara elektris (Kragh et al.,2002). Agen- agen tersebut dapat digunakan sebagai agen tunggal ataupun kombinasi untuk aktivasi, diantaranya pada oosit sapi, kelinci, dan babi, (Yang $\mathrm{X}$ et al, 1994; Liu et al, 2002; Sedmikova et al, 2003). Selain itu penggunaan CSE juga dapat dijadikan bahan aktivator dalam aktivasi parthenogenesis.

Penggunaan CSE dari beberapa hasil penelitian menunjukkan kemampuan dalam meningkatkan kadar kalsium intraseluler secara berulang (Choi et al. (2002) dan Wu et al. (1997)), hal ini mirip dengan induksi sperma pada oosit yang mengalami fertilisasi secara normal. Injeksi CSE dapat mengaktivasi semua oosit babi mulai MII hingga terbentuk pronuklei dan mampu mengalami pembelahan hingga $75 \%$ (Okada et al., 2004). Menurut Yamamoto et al. (2001) oosit Cynops pyrrhogaster yang belum terfertilisasi mengalami aktivasi lebih cepat setelah diinjeksi ekstrak sperma (SE, $33 \mathrm{nl}$ ) dan membentuk polar bodi setelah 1,5-2 jam setelah injeksi.

Namun demikian penggunaan CSE sebagai bahan aktivator dalam aktivasi parthenogenesis kambing yang kemudian dibandingkan dengan bahan aktivator lain belum banyak dilaporkan. Untuk itu perlu 
dilakukan penelitian untuk mendapatkan protocol aktivasi yang optimum pada oosit kambing sehingga respon penggunaan berbagai bahan aktivator tersebut pada aktivasi partenogenesis oosit kambing hasil IVM.

\section{BAHAN DAN METODE PENELITIAN}

\section{Bahan dan Alat}

Bahan yang digunakan dalam penelitian ini adalah oosit kambing immature yang diperoleh dengan cara mengaspirasi folikel ovarium kambing yang diambil dari RPH Sukun Malang, TCM 199 (Gibco-BRL), $\mathrm{NaHCO}_{3}$ (Merck), HEPES (USB, Ohio), FBS (Gibco-BRL), penicillin (Meiji Seika, Tokyo), streptomycin (Meiji Seika, Tokyo), $\mathrm{NaCl}$ Fisiologis 0,9\% (Merck), etanol (Merck), Ca ionophore (Sigma chemical), Crude Sperm Extract (CSE), paraffin oil (Merck), enzim hyaluronidase (Sigma chemical), FSH, LH, dan parafilm.

Alat yang digunakan dalam penelitian ini adalah falcon (Iwaki,ukuran $35 \mathrm{~mm}$ ), disposable syringe $10 \mathrm{ml}$ dengan jarum ukuran 21Gx11/2", petri dish, blue tip, yellow tip, rak tabung dan tabung reaksi, bunsen, millipore, hematokrit (Assistent), mikroskop elektron, autoklaf, oven, dan inkubator.

\section{Metode Penelitian}

Penelitian ini terdiri dari 3 perlakuan yaitu perlakuan 1, oosit hasil IVM (jam ke-30) diaktivasi dengan menggunakan etanol 7\% selama 7 menit. Perlakuan 2, oosit hasil IVM diaktivasi dengan menggunakan Ca Ionophore $20 \mu \mathrm{M}$ selama 7 menit dan perlakuan 3 dengan menggunakan CSE 2,5 $\mu \mathrm{g} / \mathrm{ml}$ selama 2 jam.

Preparasi protein CSE (crude sperm extract)

Protein CSE diperoleh berdasarkan metode yang dilakukan oleh Swan dan $\mathrm{Wu}$ et al. (1998) dalam Okada et al. (2004) dengan modifikasi, untuk mengetahui konsentrasi protein CSE secara kuantitatif dilakukan spektrofotometri dengan metode biuret.

\section{In vitro maturation}

Metode in vitro maturation (IVM) yang digunakan dalam penelitian ini adalah metode yang didasarkan pada metode Gordon (1994) yang telah mengalami modifikasi dan terdiri dari beberapa tahap yaitu tahap koleksi ovarium dari RPH, aspirasi oosit, washing oosit, seleksi oosit di bawah mikroskop dan maturasi oosit dalam inkubator $\mathrm{CO}_{2} 5 \%$ pada suhu $38,5^{\circ} \mathrm{C}$. Sedangkan oosit yang digunakan dalam penelitian ini adalah oosit dengan cumulus oophorus dan corona radiata yang kompak.

Evaluasi oosit hasil IVM dilakukan pada saat oosit dimaturasi selama 27 jam. Oosit yang sudah dimaturasi diamati perkembangan sel-sel kumulus dan keberadaan first polar body yang dimilikinya. Perkembangan sel-sel kumulus ditentukan menjadi 3 tingkat yaitu tingkat 0 (oosit dengan sel-sel kumulus yang tidak 
berkembang sama sekali), tingkat 1 (oosit dengan sel-sel kumulus yang berkembang hanya sebagian), dan tingkat 2 (oosit dengan sel-sel kumulus yang berkembang seluruhnya). Sedangkan keberadaan first polar body dapat diamati setelah sel-sel selsel kumulus yang mengelilingi oosit dihilangkan dengan cara diinkubasi dalam $0,1 \%$ enzim hyaluronidase selama 5 menit diikuti dengan pipetting pada suhu ruang. Lebih lanjut maka hanya oosit dengan first polar body dan sel-sel kumulus dengan tingkat 2 saja yang dimaturasi kembali sampai jam ke-30 IVM.

\section{Aktivasi Partenogenesis}

Metode aktivasi parthenogenesis didasarkan pada metode yang dilakukan oleh Meo et al., (2003) yang telah dimodifikasi, dengan cara sebagai berikut:

Oosit yang telah dimaturasi (jam ke-30) diwashing dengan menggunakan medium aktivasi sebanyak $2 \mathrm{x}$ dan kemudian diaktivasi dengan menggunakan 7\% etanol selama 7 menit. Sedangkan perlakuan 2, oosit hasil IVM diaktivasi dengan menggunakan Ca Ionophore $20 \mu \mathrm{M}$ selama 7 menit dan perlakuan 3 dengan menggunakan CSE 2,5 $\mu \mathrm{g} / \mathrm{ml}$ selama 2 jam. Selanjutnya sesudah dilakukan aktivasi maka oosit diwashing sebanyak $3 x$ dengan washing medium dan dilakukan in vitro culture (IVC) selama $2 \times 24$ jam.

Pada IVC jam ke-48 maka oosit yang telah diaktivasi diamati di bawah mikroskop inverted jumlah yang mengalami cleavage.

\section{Analisis Data}

Data yang didapat berupa $\%$ oosit yang mengalami cleavage dari berbagai perlakuan aktivasi parthenogenesis oosit kambing diuji dengan menggunakan uji chi square.

\section{HASIL DAN PEMBAHASAN}

Parthenogenesis adalah proses produksi embrio tanpa melalui proses fertilisasi (tanpa peran dari gamet jantan). Mittwoch (1978) dalam Rougier (2001) menyebutkan bahwa partenogenetik dapat ditempuh melalui beberapa jalur. Salah satu jalur yang bisa ditempuh yaitu melalui jalur in vitro dengan cara mematurasi oosit immature dengan menggunakan medium tertentu sehingga didapatkan oosit yang mature. Pada oosit mature, oosit akan ada dalam MII. Dengan menggunakan agen tertentu maka oosit dalam MII ini dapat diaktivasi tanpa harus menggunakan sperma sebagaimana halnya pada proses fertilisasi.

Berdasarkan hasil penelitian yang telah dilakukan menunjukkan bahwa penggunaan etanol $7 \%$ selama 7 menit, $\mathrm{Ca}$ Ionophore $20 \mu \mathrm{M}$ selama 7 menit dan penggunaan CSE $2,5 \mu \mathrm{g} / \mathrm{ml}$ selama 2 jam sebagai bahan aktivator dalam aktivasi partenogenesis oosit kambing hasil IVM menunjukkan respon yang berbeda-beda. 
Respon tersebut dapat dilihat dari Berikut ini adalah perbedaan persentase cleavage rate yang dihasilkan. cleavage rate yang dimaksudkan:

Tabel 1. Efek aktivasi dengan menggunakan etanol, ca ionophore, dan CSE terhadap cleavage rate

\begin{tabular}{|l|c|c|}
\hline \multicolumn{1}{|c|}{ Perlakuan } & Total oosit & $\begin{array}{c}\text { Jumlah oosit cleavage (mean } \pm \\
\text { S.D. })\end{array}$ \\
\hline Etanol & 125 & $88(70,40 \pm 9,85)^{\mathrm{a}}$ \\
\hline Ca ionophore & 153 & $81(52,75 \pm 5,87)^{\mathrm{b}}$ \\
\hline CSE & 251 & $109(36,33 \pm 8,5)^{\mathrm{c}}$ \\
\hline
\end{tabular}

Keterangan: angka-angka yang diikuti oleh huruf dan pada kolom yang sama berbeda nyata pada $\mathrm{P}<0,05$.

Dari tabel 1 di atas terlihat bahwa penggunaan etanol sebagai single agent untuk menstimulasi kenaikan kalsium intraseluler ternyata cukup mampu untuk menyebabkan terjadinya cleavage pada embrio partenogenetik kambing sebesar $70,40 \%$ dari 125 oosit yang diaktivasi. Sedangkan penggunaan calcium ionophore menunjukkan persentase yang lebih rendah daripada penggunaan etanol yaitu sebesar $52.75 \%$. Persentase paling rendah dari tabel 1 di atas terlihat pada oosit hasil IVM yang diaktivasi dengan menggunakan CSE yaitu sebesar 36,33\%.

$$
\text { Collas et al., }
$$
mengemukakan bahwa pada single agent aktifitas $\mathrm{H} 1$ kinase akan berkurang sebesar $11-44 \%$ pada 1 jam pengamatan dan akan reaktif kembali pada 2 jam setelah stimulasi. Untuk itu agar cleavage rate meningkat maka single agent perlu dikombinasikan dengan agen lain seperti 6DMAP maupun cycloheximide (Liu et al., 1998). Ketiga agen aktivasi ini dalam menstimulasi oosit untuk keluar dari MII memilki target yang berbeda-beda. Pada aktivasi dengan menggunakan etanol saja maupun hanya menggunakan ca ionophore saja maka single agent hanya berfungsi untuk menstimulasi kenaikan kalsium intraselluler dan mendegradasi cyclin untuk sementara waktu (bersifat temporal). Ketika kalsium intraselluler meningkat dan kemudian menurun maka degradasi cyclin akan terhenti. Perlakuan kombinasi akan efektif mengatasi permasalahan ini.

Protein ekstrak sperma atau CSE (Crude Sperm Extract) merupakan protein yang diisolasi dari sperma dan dapat digunakan dalam membantu proses IVF (In Vitro Fertilisasi). Keberhasilan ekstrak sperma untuk mengaktivasi oosit karena didukung oleh kandungan protein sperma yang sangat variasi. Salah satu protein yang ada pada CSE kambing adalah PLC $\zeta$ (phospholipase $C \zeta$ ) dengan pita protein 70 - $85 \mathrm{kDa}$ pada profil pita proteinnya (Wahyuni, 2009). PLCל ini merupakan isoform dari PLC yang berperan dalam 
osilasi kalsium pada oosit (Saunders et al. (2002) dan Rogers et al. (2004).

Mekanisme CSE dalam mengaktivasi pelepasan $\mathrm{Ca}^{2+}$ diawali dengan PLC $\zeta$ yang terkandung dalam CSE (Saunders et al., 2002) yang mampu menghidrolisis InsP3 (1,4,5-triphosphate), dan menyebabkan reseptor InsP3 berikatan dengan $\mathrm{Ca} 2+$ store pada retikulum endoplasma untuk melepaskan $\mathrm{Ca}^{2+}$ sehingga kalsium intraselluler meningkat dan oosit menjadi teraktivasi (Swann et al., 1996).

\section{KESIMPULAN DAN SARAN}

Dari hasil penelitian yang telah dilakukan maka disimpulkan bahwa:1) oosit kambing hasil IVM mampu merespon berbagai bahan aktivator pada aktivasi partenogenesis yang dilakukan; 2) Respon tertinggi berturut-turut diberikan oleh oosit kambing hasil IVM yang diaktivasi dengan menggunakan etanol $7 \%$ selama 7 menit, Ca Ionophore $20 \mu \mathrm{M}$ selama 7 menit, dan CSE 2,5 $\mu \mathrm{g} / \mathrm{ml}$ selama 2 jam.

Namun demikian untuk penelitian selanjutnya perlu dilakukan 1) karyotiping pada embrio yang dihasilkan untuk melihat kemungkinan terjadinya penyimpangan kromosom dan 2) analisis pola protein yang mempengaruhi perkembangan embrio partenogenetik kambing yang dihasilkan.

\section{DAFTAR PUSTAKA}

Choi, Y.H., C.C. Love, Y.G. Chung, D.D. Varner, M.E. Westhusin, R.C. Burghardt, and K. Hinrichs. 2002. Use of Piezo-driven Direct Nuclear
Injection and Activation with Stallion Sperm Extract to Produce Horse Nuclear Transfer Embryos. Theriogenology 58: 771-774.

Collas P., Sullivan E., dan Barnes F. 1993. Histon $\mathrm{H} 1$ kinase activity in bovine oocytes following calcium stimulation. Mol Reprod Dev. 34: 224-231.

Gordon I. 1994. Laboratory production of cattle embryos. Cab Internasional. Cambridge.

Kragh, P.M., N.R Mtango., T.J Corydon., L. Bolund., H. Callesen., and G. Vajta. 2002. Combined Electrical and Chemical Activation of Zonafree Porcine Oocytes. Abstract Reproduction, Fertility, and Development 270: 284. www.publish.csiro.au/nid/45/issue/ 896.htm.

Liu, C-T, C-H. Chen, S-P. Cheng and J-C. Ju. 2002. Parthenogenesis of Rabbit Oocytes Activated by Different Stimuli. Anim.Rep.Sci. 70: 267276.

Liu L., Ju JC., and Yang X. 1998. Differential inactivation of maturation-promoting factor and mitogen-activated protein kinase following parthenogenetic activation of bovine oocytes. Biology of Reproduction. 59: 537545.

Liu L., Ju JC., and Yang X. 1998. Parthenogenetic development and protein patterns of newly matured bovine oocytes after chemical activation. Molecular Reproduction and Development. 49: 298-307.

Meo S.C., Verde Leal CL., dan Garcia JM. 2003. Activation and early parthenogenesis of bovine oocytes treated with ethanol and strontium. Animal Reproduction Science. $\mathrm{xx}$ (2003) xxx-xxx 
Nurse P. 1990. Universal control mechanism regulating onset of $\mathrm{M}$ phase. Abstracts Nature. 344: 503508.

Okada, K., K. Miyano, and M. Miyake. 2004. Activation and Development of Pig Oocytes after Microinjection of Crude Sperm Extract. J. Mamm Ova Res. 21: 134-140.

Rogers, N.T., E. Hobson, S. Pickering, F A Lai, P Braude, and K. Swann. 2004. Phospholipase $\mathrm{C} \zeta$ causes $\mathrm{Ca}^{2+}$ oscillation and Parthenogenetic activation of Human Oocytes. Reproduction 128: 697-702.

Rougier N., and Werb Z. 2001. Parthenogenesis in mammals. Molecular Reproduction and Development. 59: 468-474.

Saunders, C.M, G.L. Mark, J. Parrington, J.C. Llewellyn, R. Jillian, and F.A. Lai. 2002. PLC $\zeta$ : a Sperm-specific trigger of $\mathrm{Ca}^{2+}$ oscillations in Eggs and Embryo development. Development 129: 3533-3544.

Sedmikova M., Burdova J., Petr J., Etrych M., Rozinek J., dan Jilek F. 2003. Induction and activation of meiosis and subsequent parthenogenetic development of growing pig oocytes using calcium ionophore A23187. Theriogenology. 60: 16091620.

Swann, K. 1996. Soluble Sperm Factors and $\mathrm{Ca}^{2+}$ release in Eggs at Fertilzation. Review of Reproduction 1: 33-39.

Wahyuni, Eva Ari. 2009. Isolasi dan Karakterisasi Protein Crude Sperm Extract (CSE) Kambing dan Sapi: Uji Potensi CSE 100kDa dalam mengaktivasi Sel Oosit. TESIS. Pasca Sarjana Unibraw.

Wu, H., C.L. He, and R.A. Fissore. 1997. Injection of a Porcine Sperm Factor Triggers Calcium Oscillations in
Mouse Oocytes and Bovine Eggs. Mol. Reprod. Dev. 46: 176-189.

Yamamoto, S., H.Y. Kubota, Y. Yoshimoto, and Y. Iwao. 2001. Injection of a Sperm Extract Triggers Egg Activation in the Newt cynops pyrrhogaster. Developmental Biology 230: 89-99 